\title{
VARIA
}

Mateusz Maria Bieczyński*

biemate@gmail.com

University of Fine Arts in Poznań

Al. Marcinkowskiego 29

60-967 Poznań, Poland

\section{The Nicosia Convention 2017: A New International Instrument Regarding Criminal Offences against Cultural Property}

\begin{abstract}
This article introduces a new treaty on the protection of cultural property: the Council of Europe's Convention on Offences relating to Cultural Property ("the Nicosia Convention"), sometimes referred to as the "Blood Antiquities Convention". Opened for signature on 19 May 2017, it is considered to be an expression of hopes regarding the prevention of destruction and illicit trade of cultural objects. The Nicosia Convention obliges its State Parties to implement common standards in criminal law in relation to cultural property. The recognition and implementation of equal measures for criminal offences can fill the gap in international cooperation in that field, particularly in times of instability or conflict. The treaty opens a new perspective, but its effectiveness depends however on the readiness of States to sign and effectively implement its regime in their respective domestic legal systems. This article focuses on the basic
\end{abstract}

\footnotetext{
* Mateusz Maria Bieczyński serves as Vice-Rector of the University of Fine Arts in Poznań. He holds Ph.D. in Legal Sciences (2011) from the Institute of Law Studies of the Polish Academy of Sciences, MA in Art History (2008) from Adam Mickiewicz University in Poznań, and LL.M. in German Law (2010) from Potsdam University. In 2013 he also graduated from the CuratorLAB - Postgraduate Program for Professionals in Arts (Konstfack - University College of Arts, Crafts and Design). Mateusz received the START scholarship for young researchers from the Foundation for Polish Science (2012) and the scholarship in the field of culture awarded by the Wielkopolska Province Marshal (2013). He is currently completing a research project titled "Philosophical background of the legal limitations on freedom of visual arts", financed by the Polish National Science Centre. He is a member of the HEURIGHT research team.
} 


\section{VARIA}

Mateusz Maria Bieczyński

questions regarding the conditions of effectiveness of this treaty, the context of its adoption, and its envisaged consequences for the protection of cultural property.

Keywords: cultural heritage, cultural property, art law, illicit trade of cultural objects, cultural vandalism, Nicosia Convention

\section{Introduction}

Since the destruction of Buddhas of Bamiyan by the Taliban in 2001, the international community has witnessed a number of grave cultural heritage crimes. ${ }^{1}$ However, every next case after the Afghan one has been considered with more care than the previous ones. This was because the destruction of the Buddhas was transmitted in all most important and influential information TV channels all over the world. The broad dissemination of high-quality pictures of religiously motivated cultural vandalism raised a number of questions as to the current meanings of ancient artefacts and their social and political functions. Hence the problem of cultural heritage destruction and the need to counteract such crimes has become a global concern. ${ }^{2}$

The destruction of cultural objects from the World Heritage List constitutes only one of the reasons for the widely-voiced concern about the lack of protection of cultural property. The second group of acts against cultural property which have brought about international reactions refer to the illicit trade in cultural material. For instance, in 2011, as a result of an international investigation, Subhash Kapoor, a well-known New York antique dealer of Indian descent, was arrested. ${ }^{3}$ It was shown that he had smuggled artefacts of ancient Indian art in the USA in exchange for more than US $\$ 100$ million since $2008 .{ }^{4}$ Many of them came from unguarded local temples still holding worship services in small Indian towns outside

1 Including, among others, the looting of museums and archaeological sites during the American invasion on Iraq in 2003, see: J.H. Merryman, A.E. Elsen, S.K. Urice, Law, Ethics and the Visual Arts, 5th edn., Wolters Kluwer, New York 2007, p. 104 and the cited literature.

2 See F. Francioni, F. Lenzerini, The Destruction of the Buddhas of Bamiyan and International Law, "European Journal of International Law" 2003, Vol. 14(4), pp. 619-651.

3 M. Marmo, N. Chazal, Transnational Crime and Criminal Justice, SAGE, Los Angeles - London - New Delhi 2016, p. 158; K. Januszkiewicz, Retroactivity in the 1970 UNESCO Convention: Cases of the United States and Australia, "Brooklyn Journal of International Law" 2015, Vol. 41(1), pp. 329-372.

4 The works smuggled in were estimated to be worth several billion dollars a year. Antiquities trafficking is one of the most profitable illegal trades in the world, just behind illegal arms and drugs; see S. Calvani, Frequency and Figures of Organized Crime in Art and Antiquities, in: S. Manacorda (ed.), Organised Crime in Art and Antiquities, ISPAC, Milano 2009, p. 29. 
the main tourist routes. Among its buyers were such prominent public institutions as the Metropolitan Museum of Art in New York, the Cleveland Museum of Art, and the Art Institute of Chicago. The scandal accompanying this discovery was so great that the return of the 200 seized art objects was celebrated in an official, high-level, widely promoted ceremony between President Barack Obama and the Indian Prime Minister Narendra Modi. ${ }^{5}$

The loss of "ownership" of culturally important objects that are hunted by smugglers and lost in international illegal circulation, as well as the fate of ancient artefacts destroyed for religious reasons are among the current challenges for the international community. The above-mentioned cases helped fuel a wider interest in a methodological approach toward the punitive dimension in the protection of cultural assets. ${ }^{6}$ Examples of illicit trafficking and destruction of cultural objects and sites also brought to the fore the broader question about the possibilities for the effective preservation of objects and sites classified as "cultural heritage" or "cultural property" in the ongoing armed conflicts on the territories of Syria (the Syrian domestic war since 2011) and Iraq (the war against ISIS since 2014). It is enough to mention the destruction of the Museum in Mosul and detonation of ancient Palmyra - both video-recorded and transmitted worldwide - to understand the international reactions of disgust. Beside politicians, people of culture and social activists, many scientists and academicians have also begun to call for the reinvigoration of the debate concerning crimes against common cultural heritage. ${ }^{7}$ This has taken place on many levels.

All of the above-mentioned tragedies can be seen as "milestones" which systematically inspired international lawyers and politicians to take a new approach to acts of cultural vandalism and illicit trade in cultural objects. Each of these worldwide events has strengthened recognition of the need for an international legal reaction. In Afghanistan, Syria, ${ }^{8}$ Iraq, and Mali, ${ }^{9}$ the international community has

\footnotetext{
5 A. Daye, U.S. Returns $\$ 100$ Million of Stolen Artifacts to India, 8 June 2016, http://edition.cnn. com/2016/06/07/us/stolen-artifacts-returned-india/index.html [accessed: 20.11.2017].

6 See: S. Manacorda, Criminal Law Protection of Cultural Heritage: An International Perspective, in: S. Manacorda, D. Chappell (eds.), Crime in the Art and Antiquities World: Illegal Trafficking in Cultural Property, Springer, New York 2011, pp. 17-50.

7 M. Lostal, Syria's World Cultural Heritage and Individual Criminal Responsibility, "International Review of Law" 2015, Vol. 3, http://dx.doi.org/10.5339/irl.2015.3 [accessed: 17.11.2017].

8 C. Stephens, Blood Antiquities: Preserving Syria's Heritage, "Chicago-Kent Law Review" 2017, Vol. 92, pp. 353-389.

9 M. Lostal, The Misplaced Emphasis on the Intangible Dimension of Cultural Heritage in the AI Mahdi Case at the ICC, "Inter Gentes - The McGill Journal of International Law \& Legal Pluralism" 2017, Vol. 1(2), pp. 45-58; K. Wierczyńska, A. Jakubowski, Individual Responsibility for Deliberate Destruction of Cultural Heritage: Contextualizing the ICC Judgment in the Al-Mahdi Case, "Chinese Journal of International Law" 2017, Vol. 16(4); W. Schabas, Al Mahdi Has Been Convicted of a Crime He Did Not Commit, "Case Western Reserve Journal of International Law" 2017, Vol. 49(1), pp. 75-102.
} 


\section{VARIA}

Mateusz Maria Bieczyński

been exposed to appalling images of cultural objects being intentionally destroyed without any moral or ethical hesitation whatsoever. These situations constitute the context in which the Council of Europe (CoE) negotiated and opened for signature a new treaty: the Convention on Offences relating to Cultural Property ("the Nicosia Convention") ${ }^{10}$ - also known in the popular media discourse under more brain-stimulating name as the "Blood Antiquities Convention".11

This article offers a general overview of circumstances surrounding the Nicosia Convention's adoption, situating this new legal instrument within a broader international law context for the protection of cultural property. An examination of its characteristics is preceded by a short introduction concerning the CoE's activities in the field of protection of "cultural heritage" and "cultural property". Subsequently, the article briefly discusses the major provisions of the new treaty and points out the new directions in protection policies established by this instrument. In conclusion, it poses the question about the possible future use of criminal law regulations as a tool for the protection of cultural heritage.

\section{Background of the Recent Action by the Council of Europe to the Struggle Against Cultural Heritage Crimes}

$\mathrm{CoE}$, as the oldest European political organization directed towards the protection of human rights and common European identity across the "old continent", also plays a crucial role in the promotion and protection of cultural heritage in the region. The CoE's activities regarding cultural heritage protection are founded in the series of conventions ${ }^{12}$ and soft law instruments: recommendations, ${ }^{13}$ resolutions, and guidelines ${ }^{14}$ of the Committee of Ministers and the resolutions, ${ }^{15}$ decla-

10 Council of Europe Convention on Offences relating to Cultural Property, 19 May 2017, CETS 221.

11 "The terrible destructions of the ancient city of Palmyra in Syria and the ruins of Nimrud in Iraq have highlighted the concern for 'blood antiquities'" - said Secretary General Thorbjørn Jagland introducing the Nicosia Convention in spring 2017: "This convention will be the first international legal instrument to fight illegal trade in the art market. It will help states to combat this criminal phenomenon effectively through a joint action at Pan European level", "Blood Antiquities": New Council of Europe Initiative to Combat Illicit Trafficking in Cultural Property, 2 March 2016, https://rm.coe.int/1680721000 [accessed: 10.11.2017].

12 Council of Europe European Convention on Offences relating to Cultural Property, 23 June 1985, ETS 119.

13 Council of Europe, Recommendation on Sustained Care of the Cultural Heritage Against Physical Deterioration due to Pollution and Other Similar Factors, 4 February 1997, Rec (97)2E; Council of Europe, Recommendation on the Integrated Conservation of Cultural Landscape Areas as Part of Landscape Policies, 11 September 1995, Rec (95)9E.

14 Council of Europe, Guidelines for the Protection of the Archaeological Heritage, Council of Europe Publishing, Strasbourg 2000; Council of Europe, Guidance on the Development of Legislation and Administration System in the Field of Cultural Heritage, Council of Europe Publishing, Strasbourg 2000.

15 See, among others: Council of Europe, Résolution $n^{\circ} 1$ on the Role of Cultural Heritage and the Challenge of Globalization, adopted at the 5th European Conference of Ministers responsible for the cultural heri- 
rations, ${ }^{16}$ and guiding principles adopted at conferences of specialized ministers in the field of cultural heritage and regional planning. ${ }^{17}$ The different CoE legal acts and policies, ${ }^{18}$ together with the UNESCO conventions, are the main factors shaping pragmatic models of state interventions aimed at the protection of cultural property ${ }^{19}$ and raising the public awareness of cultural heritage's social value in Europe. ${ }^{20}$ The aforementioned terms "cultural heritage" 21 and "cultural property" 22 are both used by the CoE in international legal instruments developed under its auspices. The first term mainly refers to tangible cultural manifestations considered as artistically, archaeologically, ethnologically, or historically valuable, but does not specifically deal with property issues. In turn, the term "cultural property" puts more emphasis on the question of legal title. Arguably, this means that both terms may refer to the same objects, but in each case seen from a different perspective. ${ }^{23}$

The term "cultural heritage" is also strictly connected with rather abstractly considered values. To understand it better it is useful to recall here, that:

The CoE was the first post-war international organization to use the term cultural heritage in an official document. European cultural heritage is the pivotal concept of its 1954 Cultural Convention. ${ }^{24}[. .$.$] The very first sentence of the Convention refers$ to a further dimension of heritage: "the ideals and principles" which are the "common heritage" of the CoE members. ${ }^{25}$

tage, 5-7 April 2001, http://conservacion.inah.gob.mx/normativa/wp-content/uploads/Documento64. pdf [accessed: 16.02.2018]; Council of Europe, Resolution Concerning the Adaptation of Laws and Regulations to the Requirements of Integrated Conservation of the Architectural Heritage, 14 April 1976, Res (76)28E.

16 Council of Europe Helsinki Declaration on the Political Dimension of Cultural Heritage Conservation in Europe, 30-31 May 1996, https://rm.coe.int/16805077fc [accessed 16.02.2018].

17 I.e. Council of Europe, Third European Conference of Ministers responsible for the cultural heritage, Malta, 16-17 January 1992.

18 See: R. Pickard, European Cultural Heritage: Review of Policies and Practice, Council of Europe Publishing, Strasbourg 2002, p. 7 and following.

19 See footnotes 10 and 12 .

20 Council of Europe Framework Convention on the Value of Cultural Heritage for Society, 27 October 2005, CETS 199.

21 Ibidem.

22 Council of Europe European Convention on Offences relating to Cultural Property, 23 June 1985, ETS 119.

23 This differentiation doesn't work in reference to legal acts of a descent other than the CoE legal system. For example, the Convention for the Protection of Cultural Property in the Event of Armed Conflict of 14 May 1954 (the so-called Hague Convention) uses the term "cultural property" without a reference to national ownership.

24 Council of Europe European Cultural Convention, 19 December 1954, ETS 18.

25 O. Calligaro, From 'European Cultural Heritage' to 'Cultural Diversity'?, "Politique Européene” 2014, Vol. 45, p. 66 . 
The term "cultural property" is interrelated to the strictly material dimension of culture. ${ }^{26}$ In the etymology of the CoE, differently than in the UNESCO conventions, ${ }^{27}$ the property aspect is clearly and consequently expressed with each use of the juxtaposition of the words "heritage" and "property". ${ }^{28}$ In other words, the CoE uses the term "cultural property" intentionally to describe the relationship between the object and the State Party as a subject of international law, also as a synonym of the legislator in the field of domestic law.

The difference between two mentioned terms is also important for the proper understanding of the Nicosia Convention, which consequently uses the term "cultural property", while mentioning "cultural heritage" only in the Preamble. The State Parties should enforce criminal norms in reference to both their "own" and "foreign" objects of "cultural property", and should do so in the name of the general interest of the world's community of people to preserve the cultural heritage of humankind. ${ }^{29}$

The final text of the Nicosia Convention was adopted by the CoE Committee of Ministers on 3 May $2017^{30}$ and opened for signature on 19 May. According to its Article 27(3) the Nicosia Convention will enter into force on the first day of the month following the expiration of a period of three months from the date on which five Signatories, including at least three Member States of the Council of Europe, have agreed to be bound by its provisions. As of December 2017 only eight Member States of the CoE have signed this treaty (Armenia, Cyprus, Greece, Italy, Portugal, San Marino, Slovenia, and Ukraine). Mexico is the only non-Member signatory. Only Cyprus has already ratified the convention, while at least five ratifications are required for its legal validation. Considering that the Nicosia Convention has been opened for signature for a short period, this result can be seen as a rather optimistic prognosis for its future legal empowerment. In comparison, the 1985 Delphi Convention ${ }^{31}$ - an unsuccessful predecessor

26 For different explanation of the meaning of both terms, see: J.H. Merryman, Two Ways of Thinking about Cultural Property, "The American Journal of International Law" 1986, Vol. 80(4), pp. 831-853.

27 See: UNESCO, The Conservation of Cultural Property with Special Reference to Tropical Conditions, prepared in co-operation with the International Centre for the Study of the Preservation and Restoration of Cultural Property, UNESCO, Paris 1968. Compare with later UNESCO conventions.

28 Compare with: M. Frigo, Cultural Property v. Cultural Heritage: A "Battle of Concepts" in International Law, "International Review of the Red Cross" 2004, Vol. 86(854), pp. 368-369.

29 Especially these passages (sentences nos 3 and 4) of the Preamble to the Nicosia Convention: "Being convinced that the diverse cultural property belonging to peoples constitutes a unique and important testimony of the culture and identity of such peoples, and forms their cultural heritage; Concerned that offences related to cultural property are growing and that such offences, to an increasing extent, are leading to the destruction of the world's cultural heritage".

30 Council of Europe Convention on Offences relating to Cultural Property, https://www.coe.int/en/web/culture-and-heritage/convention-on-offences-relating-to-cultural-property [accessed: 23.11.2017].

31 Council of Europe European Convention on Offences relating to Cultural Property, 23 June 1985, ETS 119 . 
of the Nicosia Convention - after more than 30 years has still not reached the required minimum number of Signatories and thus has not entered into force (only six States have signed it and none of them ratified it), thus remaining as a "dead letter" of international law.

The 1985 Delphi Convention constituted the first attempt by the CoE to deal with cultural heritage offences, based on the concept of common responsibility and solidarity in the protection of European cultural heritage. Parties to this international law instrument were supposed to be bound to undertake certain actions to enhance public awareness about the importance of the cultural heritage protection. They were to be obliged to co-operate in order to prevent offences against cultural property, as well as to counteract illicit cross-border traffic in cultural property. The convention also included the obligations to prohibit and suppress such offences. ${ }^{32}$ However, the main scope of this treaty was to establish methods of inter-State co-operation with respect to: 1) illicit trafficking in cultural property; and 2) its restitution. The protection was limited to different categories of cultural property listed in its Appendix II and kinds of offences catalogued in its Appendix III. The list of protected property, inspired by Article 1 of the UNESCO Convention on the Means of Prohibiting and Preventing the Illicit Import, Export and Transfer of Ownership of Cultural Property ("the 1970 UNESCO Convention"), ${ }^{33}$ and by Article 1 of the UNESCO Recommendation for the Protection of Movable Cultural Property of $1978,{ }^{34}$ included both private and public property of both a movable and immovable nature. The agreement was not ratified due to many objections regarding the practical enforcement of its provisions. For example, the Explanatory Report to the European Convention on Offences relating to Cultural Property ${ }^{35}$ listed the problem of the bona fide owner in the context of transnational restitution and the prescription of cultural heritage as one of the most important terms of reference to the considerations of the Committee of Experts on International Cooperation in the Field of Offences relating to Works of Art already in 1977. ${ }^{36}$ The major problem with this treaty lay in its failure to deal with the acquisition of stolen property in good faith, an issue seen as central to international legal efforts to protect cultural heritage. ${ }^{37}$ On the other hand,

\footnotetext{
32 S. Van der Auwera, International Law and the Protection of Cultural Property in the Event of Armed Conflict: Actual Problems and Challenges, "The Journal of Arts Management, Law, and Society" 2013, Vol. 43, pp. 175-190.

3314 November 1970, 823 UNTS 231.

3428 November 1978, http://portal.unesco.org/en/ev.php-URL_ID=13137\&URL_DO=DO_TOPIC\& URL_SECTION=201.html [accessed: 15.12.2017].

35 https://rm.coe.int/16800c96ff [accessed: 16.02.2018].

36 Ibidem, p. 2.

37 See R. Pickard, op. cit., p. 345.
} 
the problem of the unlawful transfer of cultural property was regulated in parallel by other legal regimes and monitored by bodies other then CoE (especially UNESCO, ${ }^{38}$ UNODC, ${ }^{39}$ UNIDROIT, ${ }^{40}$ and the $\mathrm{EU}^{41}$ ), which were - from the perspective of European countries - recognized as more efficient tools to enforce national interests and cultural policies. ${ }^{42}$ Yet the most important reason why the Delphi Convention was doomed to failure at the time of its drafting was that States were determined to preserve their powers in the field of criminal law. This concern, however, has started to change recently and the Delphi Convention could provide a very pertinent point of departure, particularly in relation to the question of how to best define the key offences (theft, receiving, etc.), even it if is too late to "resuscitate" this agreement due to the general belief that it was ineffective. It doesn't change the fact that the problems resulting from the existing differences in criminal legislation regarding illegal trafficking of cultural objects continue to be an obstacle. In one of the recommendations ${ }^{43}$ from 1998 the CoE pointed out that "the UNIDROIT Convention can't solve all the problems posed by the unlawful transfer of cultural objects, in particular the question of international crime rings dealing in cultural property". ${ }^{44}$

The increasing flow of cultural objects originating from conflict-ridden territories spurred the international community to search for new and more effective mechanisms of global and regional cooperation in criminal matters regarding

38 See: A. Deregibus, Recent Activities of UNESCO Regarding the Fight Against Traffic in Cultural Property, in: S. Manacorda, A. Visconti (eds.), Protecting Cultural Heritage as a Common Good of Humanity: A Challenge for Criminal Justice, ISPAC, Milano 2013, pp. 45-55.

39 S. Greenblatt, UNODC and the Fight Against Illicit Trafficking in Cultural Property, in: S. Manacorda, A. Visconti (eds.), Protecting Cultural Heritage as a Common Good of Humanity: A Challenge for Criminal Justice, ISPAC, Milano 2013, pp. 56-62.

40 UNIDROIT Convention on Stolen or Illegally Exported Cultural Objects, 24 June 1995, 34 ILM 1322 ("1995 UNIDROIT Convention").

41 Council Directive 93/7/EEC of 15 March 1993 on the return of cultural objects unlawfully removed from the territory of a Member State, OJ L 74, 27.03.1993, [replaced by:] Directive 2014/60/EU of the European Parliament and of the Council of 15 May 2014 on the return of cultural objects unlawfully removed from the territory of a Member State and amending Regulation (EU) No 1024/2012 (Recast), OJ L 159, 28.05.2014. See: S. Hristova, The European Model of Cultural Heritage Policy, "Zarządzanie w Kulturze" 2017, Vol. 18(1), pp. 1-16.

42 See: D. Thérond, The Council of Europe Conventions in the Field of Cultural Heritage and Landscape: Trends and Prospects, in: M. Guštin, T. Nypan (eds.), Cultural Heritage and Legal Aspects in Europe, University of Primorska, Koper 2010, p. 22.

43 Council of Europe, Recommendation 1372 (1998) on the UNIDROIT Convention on Stolen or Illegally Exported Cultural Property, 26 May 1998.

44 See: C. Armbrüster et al., Study on Preventing and Fighting Illicit Trafficking in Cultural Goods in the European Union by the CECOJI-CNRS - UMR 6224, Contract No. Home/2009/ISEC/PR/019-A2, Final Report - October 2011, p. 36: "The Recommendation was intended as a step on the road to adoption of the UNIDROIT Convention, but it also states that 'further international efforts are necessary to go beyond the Convention'". 
the protection of cultural heritage. ${ }^{45}$ It became clear that there is a need for a new regulatory regime designed to strengthen the international law system for the protection of cultural heritage, and thus in early 2016 the CoE decided to begin the process which would result in the adoption of the Nicosia Convention.

The new treaty act can be seen as an extension or completion of the regime of the former 1985 Delphi Convention. ${ }^{46}$ It is considered to be the only international treaty specifically dealing with criminalization of the illicit trafficking of cultural property. As such, it is designed to fill the gap within the international law system. In this regard the Nicosia Convention is intended to complement the system of global protection of cultural heritage, established primarily by the 1954 Hague Convention on the Protection of Cultural Property in the Event of Armed Conflict, ${ }^{47}$ together with its First (1954) ${ }^{48}$ and Second (1999) ${ }^{49}$ Protocols; the 1970 UNESCO Convention; and the 1995 UNIDROIT Convention.

While the legislative process underlying the Nicosia Convention was not free from serious disagreements between the CoE Member States, still it seems that the Council of Europe used the momentum of the destruction and looting of ancient monuments by ISIS for the revision of the 1985 Delphi Convention. At the 6th Council of Europe Conference of Ministers responsible for cultural heritage held in 2015 in Namur, ${ }^{50}$ Ministers condemned "the deliberate destruction of cultural heritage and the illicit trafficking of cultural property" and decided to "reinforce European cooperation" in this field, leading to a Committee of Ministers' decision to draft a new convention. In fact, the control of trafficking in cultural material constituted one of the core issues, vividly debated at preparatory sessions, noted as follows:

While importing States wanted a more lightweight instrument setting minimum criminal law standards, the exporting States wanted a very strong instrument supported by a specialised oversight body for cultural property crimes. When it came to the scope of the Convention, some representatives wanted forgeries and fakes to be covered,

45 In particular, see UN Security Council Resolution No. 2347, 24 March 2017, UN Doc. S/RES/2347 (2017).

46 See: R. Pickard, op. cit., pp. 63-65.

47 Convention for the Protection of Cultural Property in the Event of Armed Conflict, 14 May 1954, 249 UNTS 240.

48 Protocol for the Protection of Cultural Property in the Event of Armed Conflict, 14 May 1954, 249 UNTS 358.

49 Second Protocol to the Hague Convention for the Protection of Cultural Property in the Event of Armed Conflict, 26 March 1999, 2253 UNTS 21.

50 See: 6th Conference of Ministers responsible for cultural heritage (22-24 April 2015) and adopted "Namur Declaration" entitled Cultural Heritage in the 21st Century for Living Better Together. Towards a Common Strategy for Europe. 


\section{VARIA}

Mateusz Maria Bieczyński

while others insisted that false goods were a consumer protection issue rather than a criminal law one. ${ }^{51}$

This clearly shows how turbulent was the work by the CoE, initiated by the Mediterranean countries (primarily Greece, Cyprus, and Italy). Hopefully, the final compromise will be acceptable to most members of this regional organization and other countries worldwide.

\section{The New Treaty Regime}

The main restraint in the international field connected to the problem of prevention of destruction and illicit trafficking of cultural objects - as previous deliberations have shown - was the widespread conviction that the management of national heritage is a matter which concerns state sovereignty. At the same time, this principle has never been seriously called into question in the international legal discourse, and the defensive tendencies vis-à-vis state sovereignty have effectively blocked the possibility of an effective agreement that could solve the problems that are troubling the international circulation of art and antiquities. In addition, the wide-ranging market liberalization has also resulted in a lack of efficient instruments which could prevent the criminal activities related to transnational terrorism and enable the implementation of effective actions for the protection of the testimonies of civilizations represented by cultural heritage in the conflict zones.

This situation forced the $\mathrm{CoE}$ to work on the new legal instrument, which is designed to be able to protect the cultural property of any State, regardless of whether it will be a party to the convention or not. The main idea standing behind the new international agreement - the Nicosia Convention - was to bring national legislation up to the same standard of protection. Following this path, the Nicosia Convention calls upon States and intergovernmental organizations to be internationally engaged in preventing and combating illegal trade in, and the destruction of, cultural property. In this respect it can be seen as a CoE instrument in the fight against terrorism and organized crime, particularly in the context of the conflicts in Iraq and Syria. Such an intention is expressed clearly already in the Preamble, which directly refers to unlawful excavations and the illicit export and import of cultural property, as well as the involvement of organized crime and terrorist groups in these activities. The Preamble also emphasizes the value of the diversity of cultural heritage, which constitutes a unique and important human testimony. For these

51 J. Brown, The 2017 Blood Antiquities Convention - Protecting Cultural Property through Criminal Law, 4 July 2017, https://grojil.org/2017/07/04/the-2017-blood-antiquities-convention-protecting-cultural-property-through-criminal-law/ [accessed: 7.11.2017]. 
reasons the parties to the Nicosia Convention confirm their will to close the existing loopholes and to undertake more effective cross-border co-operation in investigating, prosecuting, and sentencing persons suspected of the offences listed in the convention.

These programmatic assumptions are reflected and substantiated already in Article 1, which offers the catalogue of goals to be achieved by the State Parties. Accordingly, the prevention of and combatting against such offences as destruction, damage, or trafficking directed towards cultural property should be conducted through establishing suitable criminal regulations on both the national and international levels. This cannot be achieved without the strengthening of the systems of crime prevention and the criminal justice in cases of criminal offences relating to cultural property. Finally, achievement of the mentioned goals is not possible without the promotion of national and international co-operation in combating such offences. The first step on that road should be the adaptation of common legal regulations expressed in the convention on the level of national legal systems.

The purposes of the treaty are extended by the proper criminal law regulations expressed in Chapter Two (Articles 3-16), entitled "substantive criminal law". The provisions of the Nicosia Convention contain a catalogue of crimes against cultural property, in particular: theft; conducting archaeological excavations without a permit; illegal import and export of cultural goods; breaching the fidelity of cultural goods; and the unlawful placing of cultural goods on the market. The forgery of documents and deliberate destruction or destruction of cultural property are also criminalized and subject to penalties. The list of the crimes mentioned was prepared based on a comprehensive review done by the European Committee of Crime Problems (CDPC) on the national legislation in force. This marked a starting point of concern and led to the introduction of the common standards and legislative measures to be adopted by the State Parties of the new convention.

The subject matter of the Nicosia Convention is regulated under Article 2, which provides legal definitions and delineations of the terms used in the treaty. The core notion is "cultural property"; both movable and immovable. According to Article 2(2) "movable cultural property" is defined as any object, situated on land or underwater or removed therefrom, which is, on religious or secular grounds, classified, defined, or specifically designated by any Party to the Convention or to the 1970 UNESCO Convention as being of importance for archaeology, prehistory, ethnology, history, literature, art, or science, and which belongs to one of the mentioned categories such as, inter alia, products of archaeological excavations, antiquities which are more than hundred years old, or objects of artistic interest (singly or in collections). As described in the Explanatory Report (Paragraph 24), the Convention contains a definition of cultural property which has largely been accepted at the global level, including all the CoE Members that 


\section{VARIA}

Mateusz Maria Bieczyński

have signed or ratified the 1970 UNESCO Convention, but also those bound by Directive 2014/60/EU. ${ }^{52}$ The wording "specifically designated" originates from the definition enshrined in the 1970 UNESCO Convention, whereas "classified or defined" stems from the aforementioned Directive.

The definition of immovable cultural property under Article 2(2)(b) of the Nicosia Convention reproduces the classification contained in the World Heritage Convention: ${ }^{53}$ monuments, groups of buildings, and sites. The same definition based on these three component parts of immovable cultural heritage appears in the CoE Convention for the Protection of the Architectural Heritage of Europe. ${ }^{54}$ This definition reflects a broad concept of "heritage", in that it not only covers secular structures situated on land and underwater, but also assets having a spiritual and/or religious significance to believers and communities.

As in the case of all other international agreements concerning cultural property, so too in the case of Nicosia Convention the main question in defining its substantive range of regulation was exactly what - or whose - cultural property should be protected. ${ }^{55}$ This new treaty refers to precious items (treasures), already listed or classified as such by respective registers. In this respect the Nicosia Convention covers all objects enjoying a protected status regardless of whether they are a part of a private or public collection, or still undiscovered in archaeological spots. Importantly, the regime of the Nicosia Convention covers all property designated or listed under the 1970 UNESCO Convention. ${ }^{56}$ In other words, the protection is not limited to the property of the Parties to this new CoE treaty, but also it covers cultural property classified, defined, or specifically designated by any Party to the 1970 UNESCO Convention. Moreover, the intention to extend international cooperation has additionally been strengthened by the opening of possible access to the Nicosia Convention to non-CoE Members. The signature by Mexico is the first sign that this logic can be successful. Opening the material scope of protection to everything classified as cultural property by other legal acts has to be considered as good strategy, preventing a situation whereby different legal regimes use similar legal terms with different meanings.

Articles 3-9 refer to different aspects of illegal trafficking in cultural property. Their content can be considered as a direct response to concrete practices on the black market of artworks and antiquities.

52 Directive 2014/60/EU..., p. 1.

53 Convention Concerning the Protection of the World Cultural and Natural Heritage, 16 November 1972, 1037 UNTS 151.

543 October 1985, ETS 121.

55 J. Brown, op. cit.

56 Ibidem. 
Article 3 regulates the theft and other forms of appropriation of cultural property. According to it all State Parties of the Convention should ensure that their criminal law applies to the mentioned crimes against movable cultural property as well. This provision, together with Article 4, which recommends the penalization of "unlawful excavation or removal" of cultural property, covers situations other than theft, e.g. when someone comes into possession of a cultural object without a legal (official) authorization. The drafters considered that the term "without authorization" may include the situation wherein a person has received an authorization to perform an excavation, but where he or she does so in serious breach of the conditions stated in the authorization, rendering it void in accordance with the applicable domestic law of the State that had issued the authorization.

Anticipating that stolen cultural objects are usually transported out of the country in which they were illegally obtained, the next two Articles foresee the criminalization of illegal importation (Article 5) and illegal exportation (Article 6). The provision of Article 5 presupposes that a Party has domestic legislation in place which prohibits the importation of cultural property into its territory that has been stolen, excavated, or exported in violation of the export law of another State. Under Article 6, the exportation is considered as a criminal offence where the law of the State which has classified, defined, or specifically designated cultural property expressly establishes an absolute prohibition of exportation.

According to Article 7, cultural property which was stolen, excavated, removed, imported, or exported cannot be an object of acquisition. In turn, the offence of "placing of the cultural property on the market", as defined in Article 8, is particularly interesting. The content of this term is explained in the Explanatory Report ${ }^{57}$ to the Nicosia Convention. Accordingly, it covers all acts of supplying illicitly-traded cultural property, as well as publicly offering such cultural property for sale (Paragraph 61). It refers directly to all kinds of commercial offers - official or unofficial (the so-called black market) - such as flea markets, antique shops, and auction houses, as well as online markets and social networks (Paragraph 62). This can be considered as a step forward to a better legal substantiation of "good faith" in relation to the acquisition of cultural material. Accordingly, this presumption will not refer to situations when cultural property has been acquired from an untested source. In response to those situations whereby stolen or illicitly excavated artefacts are moved to countries where they can easily be concealed from customs and border officials, where tainted titles can be laundered (for instance, through norms protecting good faith purchasers or the expiry of limitation periods) and then sold, either to private individuals or institutional collectors, or to established art trade companies such as art dealers or private galleries, 
the Convention proposes their criminalization not only when the purchasing agent or buyer knows the unlawful provenience of the object, but also in those situations when they should know that fact by exercising due diligence.

Article 10 is directed towards criminalization of the intentional damaging and destruction of cultural property. These types of conduct should be restricted by domestic law independently of the reason of the subject of such an action. The term "destruction" means the act or process of wrecking or tearing down an item of movable or immovable cultural property to the extent that it no longer exists or cannot be repaired. The term "damaging" means an act or process of changing or disfiguring the external physical integrity of cultural property, without necessarily destroying it.

Among the subsequent articles of the convention, of particular importance are the recommendations to enforce appropriate measures, both on the domestic and international levels. Article 20 obliges each Party to consider legislative and other necessary measures at the domestic level to achieve the 12 goals mentioned in points (a) to (I). The list contains activities directed towards the creation of a transparent system of cultural property protection and preservation. It refers to, inter alia, the archiving of information (inventories and databases) about cultural property, introduction of relevant import and export control procedures, and of including due diligence provisions for art and antiquity dealers, auction houses, and others involved in the trade in cultural property. Article 20 also mentions the necessity of empowering a new or already existing authority to co-ordinate the activities related to the protection of cultural property. It highlights the significance of the Internet in the circulation of cultural property by referring to: monitoring and reporting of suspicious dealings or sales on the Internet; and encouraging internet service providers, internet platforms, and web-based sellers to co-operate in preventing the trafficking of cultural property by participating in the elaboration and implementation of relevant policies. Some of the postulated measures are also directed toward museums and similar institutions and are aimed at ensuring that they do not acquire illicitly removed cultural property; provide information and training for the relevant officials on the prevention of and fight against cultural property-related offences; and that when they are not under state control they will comply with existing ethical rules on the acquisition of movable cultural property and report to law enforcement authorities any suspected trafficking in cultural property. The measures also refer to mandatory reporting to the competent authorities of the discovery by chance of cultural property of the archaeological heritage, prevention of free ports from being used for the purpose of trafficking in cultural property, and the improvement of the dissemination of information relating to any cultural property that has been the subject of an offence as defined by the Nicosia Convention to its customs and police authorities in order to prevent the trafficking of this cultural property. 
On the international level, the Convention, under Article 21, supports technical cooperation, like the organization of the awareness-raising campaigns addressed to the general public about the protection of cultural property and the dangers posed by crimes against it. Accordingly, each Party to the treaty shall co-operate to the widest extent possible for the purpose of preventing and fighting the intentional destruction of, damage to, and trafficking in cultural property. First, the actions shall be directed toward the promotion of consultation and exchange of information as regards the identification, seizure, and confiscation of cultural property that has been the subject of an offence defined by the Convention, and that has been recovered within the territory of a Member State (Article 21(a)). Second, Parties to the Nicosia Convention shall contribute to international data collection on trafficking of movable cultural property by sharing or interconnecting national inventories or databases on cultural property, so as to comprise international inventories or databases, such as the Interpol database on stolen works of art (Article 21(b)). Importantly, Article 21(c) asks States to consider facilitating co-operation for the protection of cultural property, particularly in times of instability or conflict and when cultural property is endangered in their own territory or abroad. This provision should be understood broadly in that it relates to facilitating co-operation between States as well as co-operation between States and private entities, including private entities in different States. One example is the establishment of refuges (or "safe havens"), either domestically or abroad, whereby foreign movable cultural property endangered by such situations of instability or conflict can be safely stored, conserved, and protected.

The Convention establishes a new institution responsible for the enforcement of its provisions - the Committee of the Parties, consisting of Parties' representatives and with the Secretary General of the Council of Europe as the convening person (Article 22). The first meeting should be organized during the first year following the entry into force of the convention, and subsequent plenary sessions should be convoked on the request of at least one third of Parties. The Committee's tasks are outlined very broadly (Article 24). They range from monitoring of the implementation of the Convention, through its evaluation, collection, analysis, and exchange of information, experience, and good practice between States, to identification of problems, expressing of opinions, and giving recommendations to the State Parties. Other representatives should also participate in the sessions of the Committee - the Parliamentary Assembly of the Council of Europe, the European Committee on Crime Problems (CDPC) and the Steering Committee for Culture, Heritage and Landscape (CDCPP), each of which shall appoint a representative to the Committee of the Parties in order to contribute to a multisectoral and multidisciplinary approach. In addition, Article 23 also mentions other possible participants, such as - among others - different CoE bodies, representatives of relevant international bodies as observers, repre- 


\section{VARIA}

Mateusz Maria Bieczyński

sentatives of relevant official bodies of the Parties, representatives of civil society, and in particular non-governmental organizations.

The Nicosia Convention also regulates the relationship with other international instruments (Article 25). In accordance with the 1969 Vienna Convention on the Law of Treaties, ${ }^{58}$ Article 25 seeks to ensure that the Convention harmoniously coexists with other treaties - whether multilateral or bilateral - and with other instruments dealing with matters which the Convention also covers. Article 25(1) is aimed at ensuring that this Convention does not prejudice the rights and obligations derived from other international instruments to which the Parties to this Convention are also Parties or will become Parties, and which contain provisions on matters governed by the Convention. ${ }^{59}$ Article 25(2) states positively that Parties may conclude bilateral or multi-lateral agreements - or any other legal instrument - relating to the matters which the Convention governs. However, the wording makes it clear that Parties are not allowed to conclude any agreement which derogates from this Convention. ${ }^{60}$

\section{Concluding Remarks}

Undoubtedly, the Nicosia Convention should be considered as an important tool for the unification of standards in the field of domestic criminal regulations designed to protect "cultural property", which - through better understanding of parallel and/or equal legal provisions by the State Parties - can result in more efficient cooperation on the international level. The convention complements other, already existing multilateral treaties directed both towards economical and political interests of State Parties in preserving their "cultural property", as well as towards strengthening the legitimate interest of the world community in gaining the widest possible access to culture and cultural heritage. Thanks to this dualistic content, the Nicosia Convention seems to be the first international agreement which attempts to merge different and sometimes partly contradictory aspects of culture preservation. While the proposed solutions deeply penetrate the domain traditionally reserved to States, the convention also gives them the freedom to establish their own legal solutions compatible with the general framework given by the Nicosia Convention. This openness creates the opportunity to build a real system of international standards while respecting national differences in the development of cultural policies. It also establishes a bridge by which to involve third countries, which are not CoE Member States. Seen from

5822 May 1969, 1155 UNTS 331.

59 Council of Europe, Explanatory Report... Nicosia, 19.05.2017, para. 143.

60 Ibidem, para. 144. 
this perspective, the Nicosia Convention has to be valued also for making an important contribution toward directing significant global attention to the common task of culture heritage preservation and protection. ${ }^{61}$

\section{References}

"Blood Antiquities": New Council of Europe Initiative to Combat Illicit Trafficking in Cultural Property, 2 March 2016, https://rm.coe.int/1680721000 [accessed: 10.11.2017].

Armbrüster C. et al., Study on Preventing and Fighting Illicit Trafficking in Cultural Goods in the European Union by the CECOJI-CNRS - UMR 6224, Contract No. Home/2009/ISEC/ PR/019-A2, Final Report - October 2011.

Brown J., The 2017 Blood Antiquities Convention - Protecting Cultural Property through Criminal Law, 4 July 2017, https://grojil.org/2017/07/04/the-2017-blood-antiquities-convention-protecting-cultural-property-through-criminal-law/ [accessed: 7.11.2017].

Calligaro O., From 'European Cultural Heritage' to 'Cultural Diversity'?, "Politique Européene” 2014, Vol. 45.

Calvani S., Frequency and Figures of Organized Crime in Art and Antiquities, in: S. Manacorda (ed.), Organised Crime in Art and Antiquities, ISPAC, Milano 2009.

Convention Concerning the Protection of the World Cultural and Natural Heritage, 16 November 1972, 1037 UNTS 151.

Convention for the Protection of Cultural Property in the Event of Armed Conflict, 14 May 1954, 249 UNTS 240.

Convention on the Means of Prohibiting and Preventing the Illicit Import, Export and Transfer of Ownership of Cultural Property, 14 November 1970, 823 UNTS 231.

Council Directive 93/7/EEC of 15 March 1993 on the return of cultural objects unlawfully removed from the territory of a Member State, OJ L 74, 27.03.1993.

Council of Europe Convention for the Protection of the Architectural Heritage of Europe, 3 October 1985, ETS 121.

Council of Europe Convention on Offences relating to Cultural Property, 19 May 2017, CETS 221.

Council of Europe Convention on Offences relating to Cultural Property, https://www.coe.int/ en/web/culture-and-heritage/convention-on-offences-relating-to-cultural-property, [accessed: 23.11.2017].

Council of Europe European Convention on Offences relating to Cultural Property, 23 June 1985, ETS 119.

Council of Europe European Cultural Convention, 19 December 1954, ETS 18.

61 Here one should mention the parallel initiative on the EU level, which resulted in preparation of the Proposal for a Regulation of the European Parliament and of the Council on the Import of Cultural Goods, 13 July 2017, COM(2017) 375 final, 2017/0158 (COD), which is directed against illegal trade in cultural goods and towards eliminating alternative sources of financing of terrorism, including the looting and smuggling of antiquities. 


\section{VARIA}

Mateusz Maria Bieczyński

Council of Europe Framework Convention on the Value of Cultural Heritage for Society, 27 October 2005, CETS 199.

Council of Europe Helsinki Declaration on the Political Dimension of Cultural Heritage Conservation in Europe, 30-31 May 1996, https://rm.coe.int/16805077fc [accessed: 16.02.2018].

Council of Europe, Explanatory Report to the Council of Europe Convention on Offences relating to Cultural Property, Nicosia, 19.05.2017, https://rm.coe.int/1680710437 [accessed: 16.02.2018].

Council of Europe, Explanatory Report to the European Convention on Offences relating to Cultural Property, Delphi, 23.06.1985, https://rm.coe.int/16800c96ff [accessed: 16.02.2018].

Council of Europe, Guidance on the Development of Legislation and Administration System in the Field of Cultural Heritage, Council of Europe Publishing, Strasbourg 2000.

Council of Europe, Guidelines for the Protection of the Archaeological Heritage, Council of Europe Publishing, Strasbourg 2000.

Council of Europe, Recommendation 1372 (1998) on the UNIDROIT Convention on Stolen or Illegally Exported Cultural Property, 26 May 1998.

Council of Europe, Recommendation on Sustained Care of the Cultural Heritage Against Physical Deterioration due to Pollution and Other Similar Factors, 4 February 1997, Rec (97)2E.

Council of Europe, Recommendation on the Integrated Conservation of Cultural Landscape Areas as Part of Landscape Policies, 11 September 1995, Rec (95)9E.

Council of Europe, Resolution Concerning the Adaptation of Laws and Regulations to the Requirements of Integrated Conservation of the Architectural Heritage, 14 April 1976, $\operatorname{Res}(76) 28 \mathrm{E}$.

Council of Europe, Résolution $n^{\circ} 1$ on the Role of Cultural Heritage and the Challenge of Globalization, adopted at the 5th European Conference of Ministers responsible for the cultural heritage, 5-7 April 2001, http://conservacion.inah.gob.mx/normativa/wp-content/uploads/Documento64.pdf [accessed: 16.02.2018].

Daye A., U.S. Returns $\$ 100$ Million of Stolen Artifacts to India, 8 June 2016, http://edition. cnn.com/2016/06/07/us/stolen-artifacts-returned-india/index.html [accessed: 20.11.2017].

Deregibus A., Recent Activities of UNESCO Regarding the Fight Against Traffic in Cultural Property, in: S. Manacorda, A. Visconti (eds.), Protecting Cultural Heritage as a Common Good of Humanity: A Challenge for Criminal Justice, ISPAC, Milano 2013.

Directive 2014/60/EU of the European Parliament and of the Council of 15 May 2014 on the return of cultural objects unlawfully removed from the territory of a Member State and amending Regulation (EU) No 1024/2012 (Recast), OJ L 159, 28.05.2014.

European Commission, Proposal for a Regulation of the European Parliament and of the Council on the Import of Cultural Goods, 13 July 2017, COM(2017) 375 final, 2017/0158 (COD).

Francioni F., Lenzerini F., The Destruction of the Buddhas of Bamiyan and International Law, "European Journal of International Law" 2003, Vol. 14(4).

Frigo M., Cultural Property v. Cultural Heritage: A "Battle of Concepts" in International Law, "International Review of the Red Cross" 2004, Vol. 86(854). 
Greenblatt S., UNODC and the Fight Against Illicit Trafficking in Cultural Property, in: S. Manacorda, A. Visconti (eds.), Protecting Cultural Heritage as a Common Good of Humanity: A Challenge for Criminal Justice, ISPAC, Milano 2013.

Hristova S., The European Model of Cultural Heritage Policy, "Zarządzanie w Kulturze" 2017, Vol. 18(1).

Januszkiewicz K., Retroactivity in the 1970 UNESCO Convention: Cases of the United States and Australia, "Brooklyn Journal of International Law" 2015, Vol. 41(1).

Lostal M., Syria's World Cultural Heritage and Individual Criminal Responsibility, "International Review of Law" 2015, Vol. 3, http://dx.doi.org/10.5339/irl.2015.3 [accessed: 17.11.2017].

Lostal M., The Misplaced Emphasis on the Intangible Dimension of Cultural Heritage in the Al Mahdi Case at the ICC, "Inter Gentes - The McGill Journal of International Law \& Legal Pluralism" 2017, Vol. 1(2).

Manacorda S., Criminal Law Protection of Cultural Heritage: An International Perspective, in: S. Manacorda, D. Chappell (eds.), Crime in the Art and Antiquities World: Illegal Trafficking in Cultural Property, Springer, New York 2011.

Marmo M., Chazal N., Transnational Crime and Criminal Justice, SAGE, Los Angeles-LondonNew Delhi 2016.

Merryman J.H., Two Ways of Thinking about Cultural Property, "The American Journal of International Law" 1986, Vol. 80(4).

Merryman J.H., Elsen A.E., Urice S.K., Law, Ethics and the Visual Arts, 5th edn., Wolters Kluwer, New York 2007.

Pickard R., European Cultural Heritage: Review of Policies and Practice, Council of Europe Publishing, Strasbourg 2002.

Protocol for the Protection of Cultural Property in the Event of Armed Conflict, 14 May 1954, 249 UNTS 358.

Recommendation for the Protection of Movable Cultural Property, 28 November 1978, http://portal.unesco.org/en/ev.php-URL_ID=13137\&URL_DO=DO_TOPIC\&URL_ SECTION=201.html [accessed: 15.12.2017].

Schabas W., Al Mahdi Has Been Convicted of a Crime He Did Not Commit, "Case Western Reserve Journal of International Law" 2017, Vol. 49(1).

Second Protocol to the Hague Convention for the Protection of Cultural Property in the Event of Armed Conflict, 26 March 1999, 2253 UNTS 21.

Stephens C., Blood Antiquities: Preserving Syria's Heritage, "Chicago-Kent Law Review" 2017, Vol. 92.

Thérond D., The Council of Europe Conventions in the Field of Cultural Heritage and Landscape: Trends and Prospects, in: M. Guštin, T. Nypan (eds.), Cultural Heritage and Legal Aspects in Europe, University of Primorska, Koper 2010.

UN Security Council Resolution No. 2347, 24 March 2017, UN Doc. S/RES/2347 (2017).

UNESCO, The Conservation of Cultural Property with Special Reference to Tropical Conditions, prepared in co-operation with the International Centre for the Study of the Preservation and Restoration of Cultural Property, UNESCO, Paris 1968.

UNIDROIT Convention on Stolen or Illegally Exported Cultural Objects, 24 June 1995, 34 ILM 1322. 


\section{VARIA}

Van der Auwera S., International Law and the Protection of Cultural Property in the Event of Armed Conflict: Actual Problems and Challenges, "The Journal of Arts Management, Law, and Society" 2013, Vol. 43.

Vienna Convention on the Law of Treaties, 22 May 1969, 1155 UNTS 331.

Wierczyńska K., Jakubowski A., Individual Responsibility for Deliberate Destruction of Cultural Heritage: Contextualizing the ICC Judgment in the Al-Mahdi Case, "Chinese Journal of International Law" 2017, Vol. 16(4). 